\title{
DEVELOPMENTAL FAILURE OF SWINE EMBRYOS RESTRICTED TO THE OVIDUCAL ENVIRONMENT*
}

\author{
F. A. MURRAY, JR, F. W. BAZER, J. W. RUNDELL, \\ C. K. VINGENT, H. D. WALLACE AND A. G. WARNIGK \\ Department of Animal Science, University of Florida, \\ Gainesville, Florida 32601, and Department of Animal Science \\ Louisiana State University, Baton Rouge, Louisiana 70803
}

\section{(Received 19th October 1970)}

Restriction of embryos to the oviducal environment (tube-locked embryos) does not prevent embryonic development to the early blastocyst stage in mice (Kirby, 1962; Orsini \& McLaren, 1967), rabbits (Pincus \& Kirsch, 1956; Adams, 1958), rats (Alden, 1942) and sheep (Wintenberger-Torres, 1956), though further development of the tube-locked embryos has not been observed and they degenerate (Adams, 1958; Kirby, 1962; Orsini \& McLaren, 1967). Kirby (1962) observed that mouse embryos recovered from the uterus continued to develop when transplanted beneath the kidney capsule; when tubelocked embryos were treated similarly only the trophoblast continued to develop. Kirby (1962) suggested that a 'uterine factor' was required for the development of mouse embryos beyond the blastocyst stage. Recently, Krishnan \& Daniel (1967) isolated a specific uterine protein, blastokinin, from rabbit uteri and demonstrated that blastokinin stimulated blastulation and blastocyst expansion in vitro. A similar protein, designated uteroglobin, has also been demonstrated in rabbit uterine secretions by Beier (1968) and Kirchner (1969). Uteroglobin has been demonstrated in rabbit embryo blastocoelic fluid between Days 3 and 9 of pregnancy (Hamana \& Hafez, 1970). This study was designed to determine the extent to which tube-locked swine embryos developed.

A total of nineteen crossbred gilts were checked for oestrus twice daily at 12-hr intervals with intact boars. The gilts were mated at 12 and at $24 \mathrm{hr}$, and surgery was performed on each animal between 48 and $72 \mathrm{hr}$, after the onset of oestrus. One oviduct was ligated at the uterotubal junction. The contralateral oviduct and uterine horn served as the control except that the uterus was ligated approximately $10 \mathrm{~cm}$ posterior to the uterotubal junction in ten of the gilts. The females were killed 4 to 8 days post coitum. Embryos were recovered from the uteri and oviducts by flushing with a physiological saline solution and were examined under a stereomicroscope to assess the stage of development. The diameter of embryos recovered from seven animals killed either 7 or 8 days post coitum was determined with an eyepiece micrometer. Gilts with no fertilized ova were eliminated from the experiment. Data were analysed by chi-square and the Student's $t$ test (Steel \& Torrie, 1960).

* Department of Animal Science, Florida Agricultural Experiment Station, Journal Series No. 3691. 


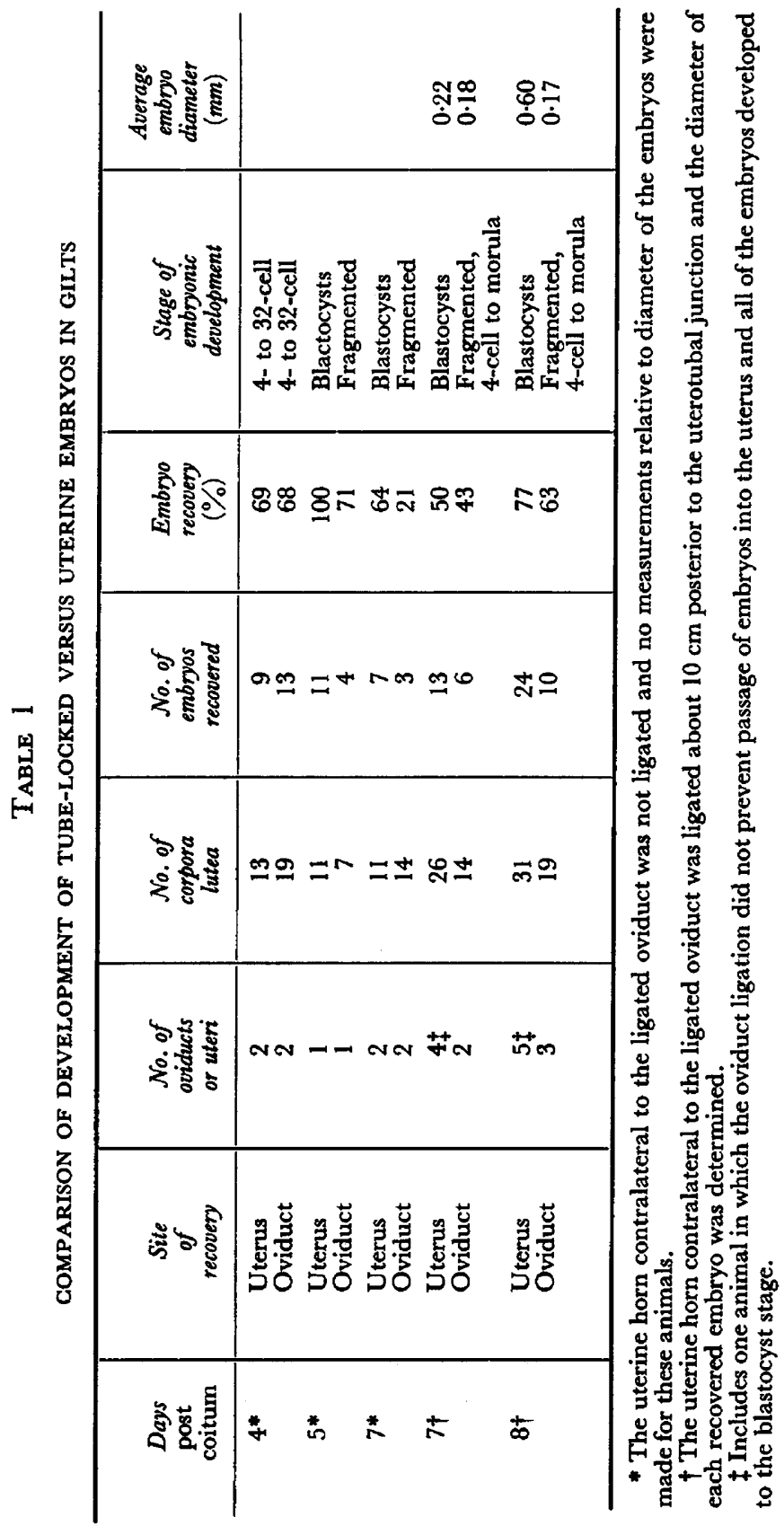




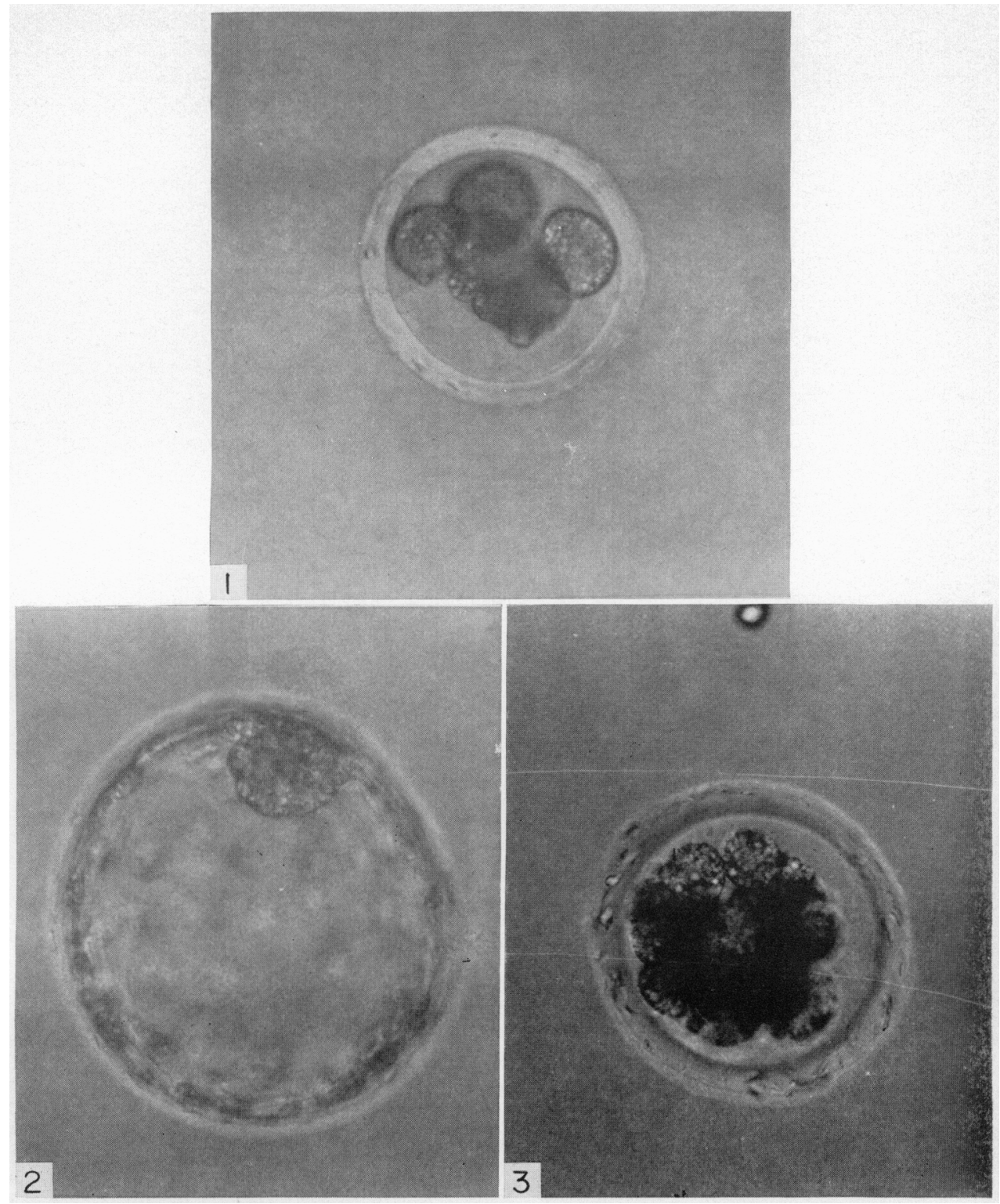

Fig. 1. A tube-locked embryo recovered from Gilt 324 at 7 days post coitum $\times 150$. FIG. 2. A utcrine blastocyst recovered from Gilt 324 at 7 days post coitum $\times 150$. Fig. 3. A tube-locked embryo recovered from Gilt 331 at 7 days post coitum $\times 150$. 
The data are summarized in Table 1. Embryos were recovered from twelve of the nineteen gilts with an overall recovery rate of $61 \%$. Recovery of tubelocked embryos $(50.7 \%)$ tended to be less than recovery of uterine embryos $(69.9 \%)$ but this difference was not statistically significant. The tendency suggests that many of the tube-locked embryos may have already disintegrated by the time of recovery, particularly by 5 days post coitum.

Tube-locked and uterine embryos were in a similar stage of development (four- to thirty-two-cells) at 4 days post coitum, implying that the oviducal environment is adequate for development of the pig embryo to the morula stage. However, pig embryos normally enter the uterus about $72 \mathrm{hr}$ after the onset of oestrus (Pomeroy, 1955) in the three- to four-cell stage of cleavage with only a small percentage beyond the eight-cell stage (Oxenreider \& Day, 1965). The blastocyst stage of development is reached between Days 5 and 6 post coitum (Perry \& Rowlands, 1962). In this experiment, the uterine embryos had undergone blastulation by 5 days post coitum while the tube-locked embryos had begun to fragment. By 7 and 8 days post coitum, the difference between uterine and tube-locked embryos was striking. The tube-locked embryos were mostly fragmented and all remained within the zona pellucida while $83.8 \%$ of the recovered uterine blastocysts had emerged from the zona pellucida, formed a distinct inner cell mass and had expanded to about three times the diameter of the zona pellucida (Plate 1). This difference in size was highly significant $(P<0.001)$.

Since no blastocysts were recovered from ligated oviducts, these data suggest that pig embryos must reach the uterine environment in order for blastulation to occur. Experiments are now in progress to determine whether the uterine endometrium of swine secretes a blastokinin-like protein $(\mathrm{s})$ which is required for continued development of the pig embryo.

\section{REFERENGES}

ADAms, C. E. (1958) Egg development in the rabbit: the influence of post-coital ligation of the uterine tube and of ovariectomy. F. Endocr. 16, 283.

ALden, R. H. (1942) Aspects of the egg-ovary-oviduct relationship in the albino rat. II. Egg development within the oviduct. F. exp. Zool. 90, 171.

BEIER, H. M. (1968) A hormone-sensitive endometrial protein involved in blastocyst development. Biochim. biophys. Acta, 160, 289.

Hamana, K. \& Hafez, E. S. E. (1970) Disc electrophoretic patterns of uteroglobin and serum proteins in rabbit blastocoelic fluid. F. Reprod. Fert. 21, 555 .

KIRBY, D. R. S. (1962) The influence of the uterine environment on the development of mouse eggs. F. Embryol. exp. Morph. 10,496.

KIRCHNER, C. (1969) Utersuchungen an uterusspezifischen glykoproteinen wahrend der fruhen Graviditat des Kaninchens Oryctolagus cuniculus. Wilhelm Roux Arch. EntwMech. 164, 97.

Krishnan, R. S. \& DaNiEL, J. C., JR (1967) 'Blastokinin': Inducer and regulator of blastocyst development in the rabbit uterus. Science, $\mathcal{N} . X .158,490$.

Orsini, M. W. \& McLaren, A. (1967) Loss of the zona pellucida in mice and the effect of tubal ligation and ovariectomy. F. Reprod. Fert. 13, 485.

Oxenreider, S. L. \& Day, B. N. (1965) Transport and cleavage of ova in swine. F. Anim. Sci. 24, 413.

Prrry, J. S. \& Rowlands, I. W. (1962) Early pregnancy in the pig. J. Reprod. Fert. 4, 175.

Pincus, G. \& Kirsch, R. E. (1956) The sterility in rabbits produced by injection of oestrone and related compounds. Am. F. Physiol. 115, 219. 
Pomeroy, R. W. (1955) Ovulation and the passage of ova through the Fallopian tubes in the pig. 7. agric. Sci. 45, 327.

Steer, R. G. D. \& Torrie, J. H. (1960) Principles and procedures of statistics. McGraw-Hill, New York.

WiNTENBERGER-ToRres, S. (1956) Les rapports entre l'oeuf en segmentation et le tractus maternel chez la brebis. Third Int. Congr. Anim. Reprod., Cambridge, 1, 62. 